\title{
Indirect nitrogen losses of managed soils contributing to greenhouse emissions of agricultural areas in Austria: results from lysimeter studies
}

\author{
Alexander Eder • Günter Blöschl • Franz Feichtinger • Markus Herndl • \\ Gernot Klammler · Johannes Hösch • Eva Erhart • Peter Strauss
}

Received: 18 August 2014/ Accepted: 11 February 2015/Published online: 19 February 2015

(C) The Author(s) 2015. This article is published with open access at Springerlink.com

\begin{abstract}
A considerable share of greenhouse gas emissions, especially $\mathrm{N}_{2} \mathrm{O}$, is caused by agriculture, part of which can be attributed to indirect soil emissions via leaching and runoff. Countries have to report their annual emissions, which are usually calculated by using the default value of 0.3 for $\mathrm{Frac}_{\mathrm{LEACH}}$, a factor that represents the fraction of nitrogen losses compared to total nitrogen inputs and sources. In our study we used 22 lysimeters, covering a wide range of soils, climatic conditions and management practices in Austria, to evaluate nitrogen losses through leaching and to calculate $\mathrm{Frac}_{\mathrm{LEACH}}$. The terms of the nitrogen mass balance of the lysimeters were directly measured for several years. Both grassland and arable land plots gave significantly smaller values of Frac $_{\text {LEACH }}$ than the default value. For grassland, Frac $_{\mathrm{LEACH}}$ values of only 0.02 were found which varied very little over the entire observation
\end{abstract}

A. Eder $(\bowtie) \cdot$ F. Feichtinger · P. Strauss

Institute for Land and Water Management Research,

Federal Agency for Water Management, Pollnbergstraße

1, 3252 Petzenkirchen, Austria

e-mail: alexander.eder@baw.at

G. Blöschl

Institute of Hydraulic Engineering and Water Resources

Management, Vienna University of Technology,

Karlsplatz 13/222, 1040 Vienna, Austria

M. Herndl

Agricultural Research and Education Centre Raumberg-

Gumpenstein, Raumberg 38, 8952 Irdning, Austria period. For arable sites, Frac $\mathrm{LEACH}_{\text {values were higher }}$ (around 0.25) and showed significant variability between years due to variations in crop rotation, fertilization rates, and yields.

Keywords Nitrogen leaching - Lysimeter - IPCC · Agricultural emissions

\section{Introduction}

As part of the second commitment period of the Kyoto protocol, 37 countries have agreed to legally binding reductions in their greenhouse gas emissions. To be able to evaluate the progress in achieving the emission reduction goal, annual national inventory reports must be compiled and submitted to the United Nations

G. Klammler

Institute for Water, Energy and Sustainability, Joanneum

Research Graz, Elisabethstraße 18/II, 8010 Graz, Austria

J. Hösch

Institute for Soil, Health and Plant Nutrition, Austrian Agency for Health and Food Safety, Spargelfeldstraße 191, 1226 Vienna, Austria

E. Erhart

Bioscience Austria, Esslinger Hauptstrasse 132-134, 1220 Vienna, Austria 
Framework Convention on Climate Change (UNFCCC). The Intergovernmental Panel on Climate Change (IPCC), which was set up by the World Meteorological Organization (WMO) and the United Nations Environment Program (UNEP), established guidelines which provide internationally agreed methodologies intended for use by countries to calculate greenhouse gas inventories to report to the UNFCCC (IPCC 2006).

One of the listed greenhouse gases is nitrous oxide, $\mathrm{N}_{2} \mathrm{O}$, which has a global warming potential 296 times higher than carbon dioxide over a 100 year time scale. In Austria, the main sources of nitrous oxide emissions are agriculture, forestry and other land uses with a share of $59 \%$ in the national total nitrous oxide emissions, although these sectors contribute only $9.1 \%$ to the total Austrian greenhouse gas emissions (Environment Agency Austria 2013). $3.69 \mathrm{Gg} \mathrm{N}_{2} \mathrm{O}$ were considered indirect soil emissions via nitrogen leaching, based on the Austrian National Inventory (Environment Agency Austria 2013). In Austria, manure, mineral fertilizer and plant residues are applied to soils, supplying nitrogen as a nutrient for plants. Depending on the environmental conditions, some of the nitrogen is leached as nitrate, nitrite or ammonia. These nitrogen losses can be calculated as a fraction of all nitrogen added to or mineralized in soils, a parameter that is termed Frac $_{\text {LEACH }}$. A part of the lost nitrogen is transformed to $\mathrm{N}_{2} \mathrm{O}$.

Mosier et al. (1998) suggested a value of 0.3 for Frac $_{\text {LEACH }}$, which is the value recommended in the IPCC Guidelines (IPCC 2000, 2006) as a default value. It was largely based on mass balance studies comparing agricultural nitrogen inputs to nitrogen recovered in rivers. According to the IPCC Guidelines 2006 (IPCC 2006) Frac LEACH $_{\text {should be assumed as }}$ zero for dryland regions without irrigation where precipitation is lower than evapotranspiration throughout most of the year and leaching is unlikely to occur. In humid regions Frac $_{\mathrm{LEACH}}$ should range from 0.1 to 0.8 depending on agricultural practices. Lower values than 0.3 for Frac LEACH $_{\text {can }}$ be used if more specific data are available (IPCC 2006). Many countries established country-specific values since research studies usually demonstrate lower values of Frac $_{\text {LEACH }}$ (Table 1). For example, farm scale studies and larger, catchment based studies in Ireland suggest that approximately ten percent of all applied nitrogen is lost through leaching, i.e. Frac $_{\mathrm{LEACH}}=0.1$
Table 1 Frac $_{\text {LeACH }}$ values smaller than default $(0.3)$ and countries of use

\begin{tabular}{ll}
\hline Country & Frac $_{\text {LEACH }}$ \\
\hline Belgium & 0.12 \\
Canada & 0.18 \\
Finland & 0.15 \\
Ireland & 0.10 \\
Kazakhstan & 0.06 \\
Liechtenstein & 0.20 \\
Netherlands & 0.12 \\
New Zealand & 0.07 \\
Norway & 0.18 \\
Slovakia & 0.14 \\
Switzerland & 0.20 \\
Ukraine & 0.21 \\
\hline
\end{tabular}

(Environment Protection Agency Ireland 2011; Del Prado et al. 2006; Ryan et al. 2006; Neill 1989).

Thomas et al. (2005) found that a Frac LEACH $_{\text {value }}$ of 0.07 is appropriate for New Zealand's dairy and sheep farming systems. In contrast, the calculates for New Zealand's arable and intensive vegetable systems are close to the IPCC default value of 0.3. Switzerland

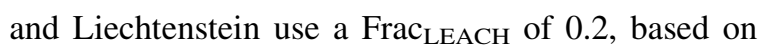
Prasuhn and Braun (1994), Braun et al. (1994) and Prasuhn and Mohni (2003) where long-term monitoring and modelling studies were conducted in the canton of Bern.

In Austria, the default value of 0.3 has so far been used as no accurate calculations have been available. However, in the light of the studies in other countries there is reason to believe that this value overcalculates the actual fraction of indirect soil emissions. The purpose of this paper therefore is to calculate values of Frac $_{\text {LEACH }}$ for different land uses and management practices in Austria in order to obtain reliable but upper bound calculates for the entire country.

One attractive way of estimating nitrogen leaching are lysimeters (Kroeze et al. 2003; Williamson et al. 1998; Scholefield et al. 1993; Chichester 1977). In fact, the use of direct lysimetry methods (as opposed to model calculates based on measured water content and soil water tension in different horizons) has increased in popularity in Europe in recent years due to its relatively better accuracy for long term calculations (von Unold and Fank 2008). In Austria various lysimeters are operated on both grassland and crop land which are used here to calculate the nitrogen losses. 


\section{Methodology}

The IPCC 'Tier 1' method provides a calculation method for estimating $\mathrm{N}_{2} \mathrm{O}$ emissions from leaching and runoff (Eq. 1)

$$
\begin{aligned}
N_{2} O_{(L)}-N= & \left(F_{S N}+F_{O N}+F_{P R P}+F_{C R}+F_{S O M}\right) \\
& \cdot \operatorname{Frac}_{L E A C H} \cdot E F_{5}
\end{aligned}
$$

where $\mathrm{N}_{2} \mathrm{O}_{(\mathrm{L})}-\mathrm{N}$ is the annual amount of $\mathrm{N}_{2} \mathrm{O}$ nitrogen produced by leaching and runoff of nitrogen additions to managed soils $\left(\mathrm{kg} \mathrm{year}^{-1}\right), \mathrm{F}_{\mathrm{SN}}$ is the annual amount of mineral fertilizer nitrogen applied to soils $\left(\mathrm{kg} \mathrm{year}^{-1}\right), \mathrm{F}_{\mathrm{ON}}$ is the annual amount of managed animal manure, compost, sewage sludge and other organic nitrogen additions applied to soils $\left(\mathrm{kg} \mathrm{year}^{-1}\right), \mathrm{F}_{\mathrm{PRP}}$ is the annual amount of urine and dung nitrogen deposited by grazing animals $\left(\mathrm{kg}\right.$ year $\left.^{-1}\right), \mathrm{F}_{\mathrm{CR}}$ is the amount of nitrogen in crop residues (above and below ground, including nitrogen fixing crops, and from forage/pasture renewal, returned to soils annually $\left(\mathrm{kg} \mathrm{year}^{-1}\right), \mathrm{F}_{\mathrm{SOM}}$ is the annual amount of nitrogen mineralised in soils associated with loss of soil carbon from soil organic matter as a result of changes in land use or land management $\left(\mathrm{kg} \mathrm{year}^{-1}\right)$, Frac $_{\text {LEACH }}$ is the fraction of all nitrogen added to or mineralised in managed soils that is lost through leaching and runoff in $\left(\mathrm{kg} \mathrm{kg}^{-1}\right)$ and $\mathrm{EF}_{5}$ is the emission factor for $\mathrm{N}_{2} \mathrm{O}$ emissions from nitrogen leaching and runoff $\left(\mathrm{kg} \mathrm{kg}^{-1}\right)$.

In total, 22 lysimeter at seven sites in Austria were used for the mass balance studies in this paper. We use the term lysimeter for a container, filled with disturbed or undisturbed soil, where percolating water is collected either gravimetrically or through suction racks with a negative soil water pressure head (www. lysimeter.at). Limitations of lysimeters usually are their inability to deal with lateral pathways of water flow.

The individual terms of Eq. 1 were measured as part of the lysimeter setup (Fig. 1). In our study, only the ratio of nitrogen leaching losses to the total $\mathrm{N}$ inputs was of interest, so no conversion to nitrous oxide was required. No grazing was executed and thus no $\mathrm{N}$ inputs of urine and dung $\left(\mathrm{F}_{\mathrm{PRP}}\right)$ needs to be taken into account. For our study, $\mathrm{F}_{\text {SOM }}$ was kept constant because no conversion from grassland or forest to arable land was performed and organic carbon content was assumed constant over the observation period.

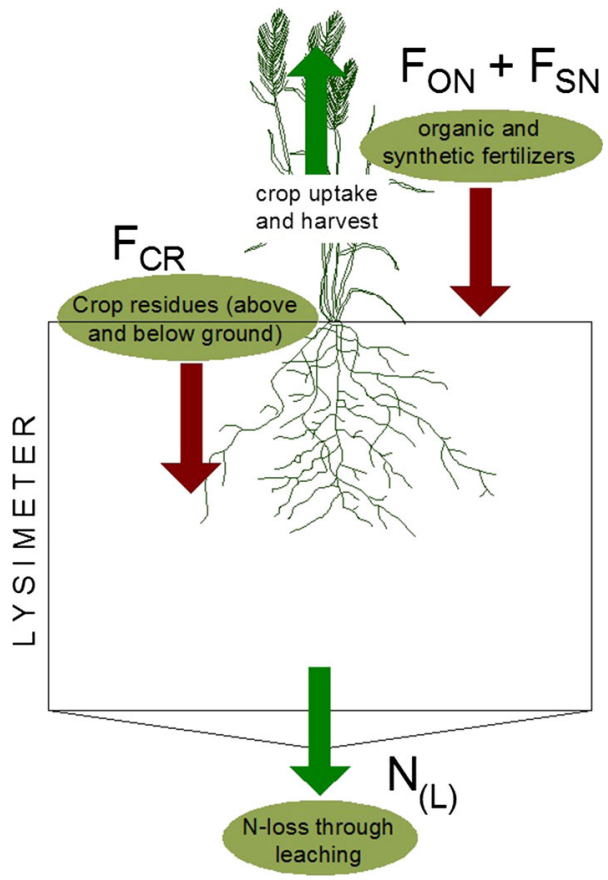

Fig. 1 Measured quantities of the nitrogen inputs and outputs (bright ellipses) of the lysimeters (see Eq. 2). Crop uptake and harvest are needed for estimating $\mathrm{F}_{\mathrm{CR}}$

Following our assumptions Eq. 1 can then be rewritten in terms of directly measurable quantities (Eq. 2).

$\operatorname{Frac}_{L E A C H}=N_{(L)} /\left(F_{S N}+F_{O N}+F_{C R}\right)$,

where $\mathrm{N}(\mathrm{L})$ are the nitrogen losses through leaching. The terms of Eq. 2 were calculated from the quantity and quality of the leaching water at the individual sites.

14 out of the 22 lysimeters are located on arable land. The remaining eight lysimeters are located on grassland. They cover a wide range of soils, climatic conditions and management practices typical of Austrian agricultural land (Fig. 2). At some sites more than one lysimeter was available with differences in soil type, land use or land management.

The various lysimeter sites are maintained by different organisations. Therefore, the sizes and measuring principles differ. At some sites, a suction rack is placed at the bottom and used for water collection; at other sites a simple gravity collection of seepage water is performed. Some lysimeters have been filled with disturbed soil at their installation; some are built up of undisturbed soil monoliths. A further distinction is soil 


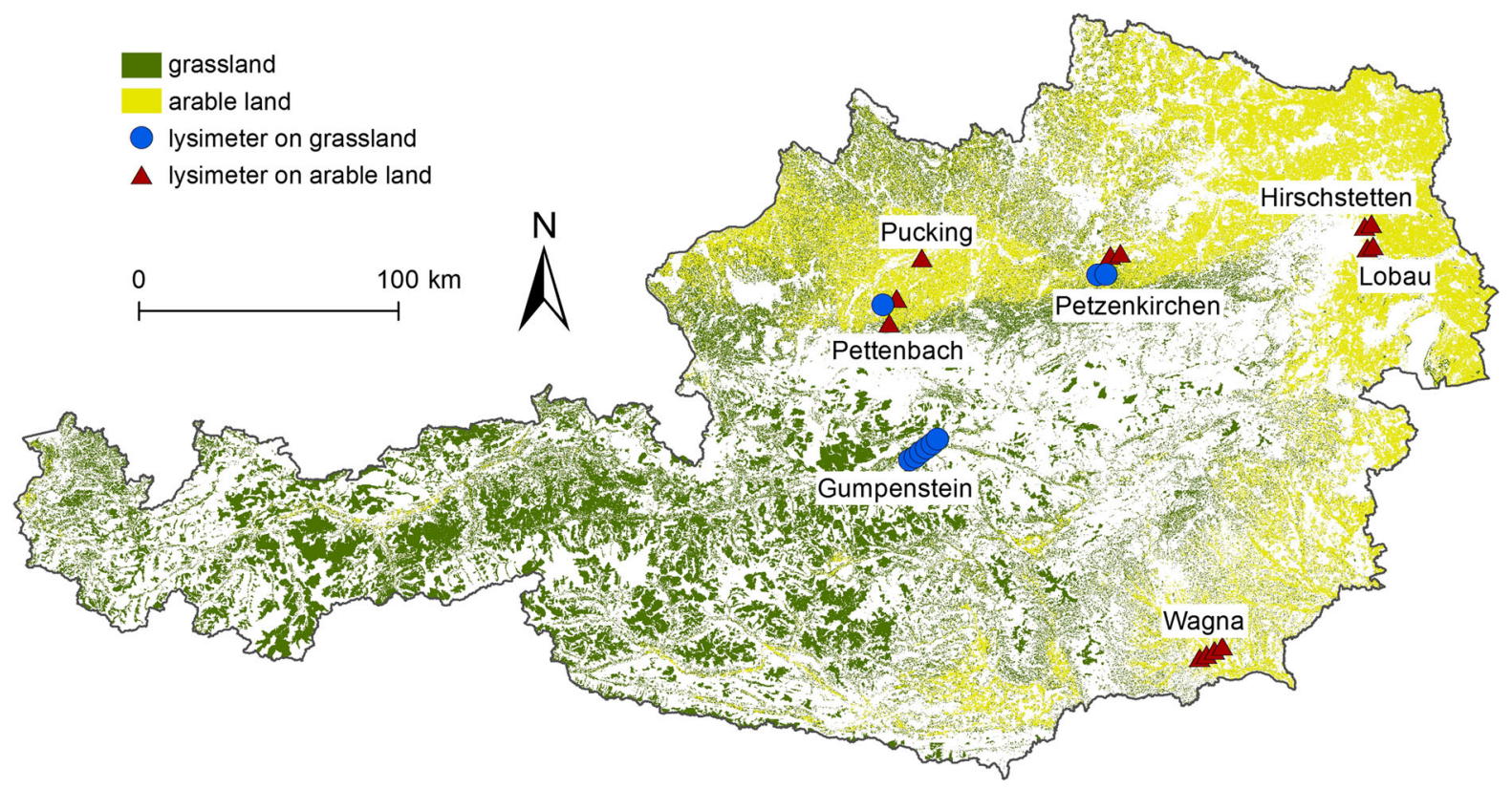

Fig. 2 Lysimeter sites and agricultural land use in Austria. Circles show sites on grassland, whereas triangles represent sites on crop land

depth and therefore the depth of water collection. The terms of the mass balance equation (Eq. 2) are all measured and can be used for estimating Frac $_{\mathrm{LEACH}}$. An exception is $F_{C R}$, the plant residues. Because below ground plant residues are not determined every year at each site. They were obtained according to the IPCC guidelines by calculating the root mass as a fraction of yield at sites and years of missing data. Above ground residues are measured at most sites. Root mass as well as $\mathrm{N}$-content of crops was calculated according to IPCC guidelines.

\section{Site description}

The key data of the lysimeter sites are summarized in Table 2. The description contains number of lysimeters at the site, year of installation, duration of measurement and installation method, surface area, sampling depth and sampling strategy, land use and fertilization, and-if necessary-important site specific notes.

\section{Petzenkirchen}

In Petzenkirchentwo undisturbed lysimeters (Petz and Petz $_{\text {syn }}$ )were installed in 1989 and operated until 2001.
The lysimeters are located at $245 \mathrm{~m}$ a.s.l. on a low terrace of the River 'Große Erlauf', soil type is Eutric Cambisol (WRB 2006) from fine sediments above gravel. Typically, the ground water table is four to five meters below surface. Surface area is $0.35 \mathrm{~m}^{2}$ and seepage water is collected at a depth of $110 \mathrm{~cm}$ under gravity conditions and analysed for nitrate and ammonia on a weekly basis (Feichtinger et al. 2004). At the Petzenkirchen site, arable land was turned to fallow in August 1994. On the Petz $\mathrm{syn}_{\mathrm{sy}}$ site only mineral fertilizer was applied whereas on the Petz site mainly organic fertilizer was used with supplement of mineral fertilizer on demand. In 1995 both lysimeters were converted to fallow management with two cuts a year. Due to the change in land use we split the time series into two periods (1990-1994: Petz 1 and Petz syn $_{1}$;

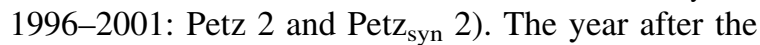
change (1995) was not included in the calculation; the effects on nitrogen leaching of the land use changes are discussed in the results section.

\section{Wagna}

In Wagna two lysimeters were filled in 1989. In 2004, the lysimeter station was renewed and both gravity lysimeters were replaced by undisturbed lysimeters with adjustable suction racks at the bottom (von 
Table 2 Overview of the lysimeter sites used in this paper. Rainfall (P), annual leaching (L), surface area, sampling depth (z), lysimeter type, sampling strategy, soil types and land use are shown

\begin{tabular}{|c|c|c|c|c|c|c|c|c|}
\hline Site & $\mathrm{P}\left(\mathrm{mm}\right.$ year $\left.^{-1}\right)$ & $\mathrm{L}\left(\mathrm{mm}\right.$ year $\left.^{-1}\right)$ & Surface area $\left(\mathrm{m}^{2}\right)$ & $\mathrm{z}(\mathrm{cm})$ & Type & Sampling & Soil type & Land use \\
\hline Petz 1 & 723 & 208 & 0.35 & 110 & Undis. & Gravity & Eutric Cambisol & Arable land \\
\hline Petz $_{\text {syn }} 1$ & 723 & 297 & 0.35 & 110 & Undis. & Gravity & Eutric Cambisol & \\
\hline Wag $_{\text {con }} 1$ & 914 & 340 & 1 & 70 & Disturbed & Gravity & Dystric Cambisol & \\
\hline $\mathrm{Wag}_{\text {con }} 2$ & 914 & 351 & 1 & 200 & Undis. & Suction & Dystric Cambisol & \\
\hline Wag $_{\text {bio }} 1$ & 914 & 228 & 1 & 110 & Disturbed & Gravity & Dystric Cambisol & \\
\hline Wag $_{\text {bio }} 2$ & 914 & 337 & 1 & 200 & Undis. & suction & Dystric Cambisol & \\
\hline Peba 1 & 1030 & 307 & 1 & 150 & Undis. & Suction & Eutric Cambisol & \\
\hline Peba 3 & 1030 & 362 & 1 & 150 & Undis. & Suction & Orthic Luvisol & \\
\hline Puck 1 & 753 & 339 & 1 & 150 & Undis. & Suction & Eutric Cambisol & \\
\hline Lob 1 & 534 & 120 & 1 & 150 & Undis. & Gravity & Calcaric Fluvisol & \\
\hline Lob 2 & 534 & 120 & 1 & 150 & Undis. & Gravity & Calcaric Fluvisol & \\
\hline Lob 3 & 534 & 120 & 1 & 150 & Undis. & Gravity & Calcaric Fluvisol & \\
\hline $\mathrm{Hir}_{\mathrm{s}}$ & 520 & 120 & 2 & 250 & Disturbed & Gravity & Chernozem & \\
\hline $\mathrm{Hir}_{\mathrm{t}}$ & 520 & 120 & 2 & 250 & Disturbed & Gravity & Chernozem & \\
\hline Petz 2 & 723 & 173 & 0.35 & 110 & Undis. & Gravity & Eutric Cambisol & Grassland \\
\hline Petz $z_{\text {syn }} 2$ & 723 & 222 & 0.35 & 110 & Undis. & Gravity & Eutric Cambisol & \\
\hline Peba 2 & 1030 & 446 & 1 & 150 & Undis. & Suction & Eutric Cambisol & \\
\hline Gump 1 & 1013 & 464 & 1 & 150 & Undis. & Gravity & Dystric Cambisol & \\
\hline Gump 2 & 1013 & 584 & 1 & 150 & Undis. & Gravity & Dystric Cambisol & \\
\hline Gump 3 & 1013 & 1068 & 1 & 150 & Undis. & Gravity & Dystric Cambisol & \\
\hline Gump 4 & 1013 & 499 & 1 & 150 & Undis. & Gravity & Dystric Cambisol & \\
\hline Gump 5 & 1013 & 508 & 1 & 150 & Undis. & gravity & Dystric Cambisol & \\
\hline
\end{tabular}

Unold and Fank 2008). The applied matric potential at the lysimeter bottoms equal the measured matric potential in the undisturbed soil beside the lysimeters. Surface area is $1 \mathrm{~m}^{2}$ and soil type is Dystric Cambisol on a terrace of Würm ice age. Before the renewal of the lysimeters, seepage water was collected at a depth of 70 and $110 \mathrm{~cm}$, respectively. In 2004 the collection depth was transferred to $2 \mathrm{~m}$. The ground water table is approximately at a depth of $4 \mathrm{~m}$. Management was adapted in order to understand the impact of agricultural practices in three phases. First, the typical crop rotation maize-maize-winter cereal-winter rape was investigated with respect to a regional yield increase. Since 1998 the reduction of $\mathrm{N}$-fertilizers became the primary topic of interest due to increasing nitrate concentrations in the Murtal aquifer. The Murtal aquifer is a significant resource for regional drinking water supply. From 1998, no fertilisation was applied in fall. Additionally, oil pumpkin became more and more attractive in the region. Therefore, oil pumpkin replaced winter rape in the crop rotation. One of the new lysimeters (after 2004) was run according to the guidelines for low $\mathrm{N}$-input farming (BMLFUW 2006), the other one was run according to the guidelines for organic farming (EC 1991). Unfortunately, the biomass of catch crops was not recorded. Left on the fields they add to the mineralisation pool and have to be taken into account for the mass balance (Klammler and Fank 2014). For this reason, the biomass of the catch crop was modelled with Simwaser (Stenitzer 1988), a physically based model that simulates the interplay of soil water and crop development. The model was calibrated on seepage water and crop yield. The time series of Wagna was also split into two periods according to the renovation works and change of management strategy in 2004 (1990-2003: Wag con $_{1}$ and Wag bio $_{1 ;}$ 2005-2012: $\mathrm{Wag}_{\text {con }} 2$ and $\mathrm{Wag}_{\text {bio }} 2$ ). 
Pettenbach

In Pettenbach three undisturbed lysimeters were installed in 1995. The identical lysimeters have a surface area of one square meter and are installed at an altitude between 426 and $455 \mathrm{~m}$ a.s.l. on deep Eutric Cambisols (Peba 1 and Peba 2) and Ortic Luvisol (Peba 3). Water is collected at a depth of $1.5 \mathrm{~m}$ with a double strategy. Free draining water is measured with a tipping bucket. Additionally, a suction rack with a negative potential of approximately field capacity $(60 \mathrm{~cm}$ water column) gives results that are more typical of field conditions (Murer 2002). The fields where the lysimeters are installed are managed by different farmers. Two of them are placed on arable land (Peba 1 and Peba 3), one is placed on grassland (Peba 2) and the management follows local practice. Additionally to the animal slurry, mineral fertilizer was applied to the Peba 1 site. Peba 2 was subject to the same fertilizer management but was used as grassland. At the Peba 3 site, organic and mineral fertilizer was applied until 1999. Later, only mineral fertilizer was used.

\section{Pucking}

In Pucking (Puck 1) a lysimeter identical in size, shape, sampling strategy and depth to those at Pettenbach site was installed in 1995 at an altitude of $288 \mathrm{~m}$ a.s.l. The significant difference to the lysimeters in Pettenbach is the very shallow soil (rooting depth of $60 \mathrm{~cm}$ ). The soil type is an Eutric Cambisol. The field is used as arable land and nitrogen is applied in form of biogas slurry.

\section{Gumpenstein}

At site Gumpenstein, five identical lysimeters are in use since 2000 (Herndl et al. 2013). The undisturbed lysimeters are built of Eutric Cambisol on fluvial glacial sediments and have a surface of one square meter. Seepage water is collected in a depth of $1.5 \mathrm{~m}$ under gravimetric potential. The application of organic fertilizers from cow excrements was done as slurry and manure and the amount was based on local practice. No mineral fertilizer was applied. The number of cuts depends on the amount of fertilizer added with increasing amount of nitrogen added and number of cuts from Gump 1 to Gump 5.
Lobau

In the Western Marchfeld area, an intensively used agricultural region, three undisturbed lysimeters with a surface area of one square meter has been constructed in 1998. The soil is a Calcaric Fluvisol. Both measuring principles (gravity and suction rack) are used for water collection on a biweekly basis in a depth of $1.5 \mathrm{~m}$. The ground water table is about $2.2-3 \mathrm{~m}$ below the surface and may influence the soil water budget in the natural surroundings of the lysimeters. However, the bottom of the lysimeters disconnects the water transfer from the groundwater to the lysimeter. Main goal of the installations was the evaluation of the differences between organic farming (Lob 3) and mineral fertilisation (Lob 2). Lysimeter Lob 1 is used as a control without adding any fertilizer (Erhart et al. 2007). Management and crop rotation follow the local practice, although application of mineral fertilizer was stopped in 2006. The last nitrogen input by compost was done in 2003.

\section{Hirschstetten}

At the Hirschstetten site, data of 18 lysimeters consisting of three soil types in six replicates are available from 1999 to 2002 . The lysimeters had been filled horizon-wise according to the natural occurrence of the soils in the Marchfeld area. Very high clay contents and big drying cracks between the lysimeter walls and soil caused a lot of preferential flow for one soil type. This does not reflect natural behaviour and we therefore excluded six of the lysimeters from further calculations. Only two soil types (sandy Chernozem $\mathrm{Hir}_{\mathrm{s}}$ and silty Chernozem $\mathrm{Hir}_{\mathrm{t}}$ ) with six lysimeters each were therefore used. Collection of seepage water is done in $2.5 \mathrm{~m}$ below ground using gravimetric potential. The surface area is two square meters (Stenitzer and Fank 2008). For this paper, mean values of the six lysimeters were used because management, crop rotation, fertilization and meteorological inputs and therefore results were similar. Only mineral fertilizer is applied.

\section{Results and discussion}

Based on the lysimeter results, harvest analyses and various accompanying measurements, the individual 
terms of the nitrogen mass balance (Fig. 1) were either measured directly or calculated indirectly to derive Frac $_{\text {LEACH }}$ (Table 3).

\section{Correction of leaching rates}

At those sites where the measurements were made by gravity lysimeters, with air pressure acting on the outflow seepage rate may be underestimated, especially in dry regions (Stenitzer and Fank 2008). Therefore we replaced the leaching rates at sites Hirschstetten and Lobau by a mean annual leaching rate of $120 \mathrm{~mm} \mathrm{year}^{-1}$, which was found to be more representative in model simulations studies for this area (Stenitzer and Fank 2008). At the Wagna site, which is wetter, the difference between the two types of lysimeters was calculated as being $<10 \%$ (Stenitzer and Fank 2008). To account for this measurement error, the seepage rates at the $\mathrm{Wag}_{\text {con }} 1$ and $\mathrm{Wag}_{\text {bio }} 1$ sites were therefore increased by $10 \%$. The same correction was applied to the other gravity lysimeters in regions with annual rainfall around or higher than $800 \mathrm{~mm} \mathrm{year}^{-1}\left(\right.$ Petz 1, Petz syn $_{1}$, Petz 2, Petz syn $_{2}$, and Gump 1-Gump 6) following the results of Stenitzer and Fank (2008) and Dowdell and Webster (1980). Nitrogen concentrations were used as measured. The leaching rates of lysimeters with a suction rack were not corrected.

Due to this correction we artificially enlarged the nitrogen pool, because the nitrogen which is leached in theory is still in the lysimeter. The remaining nitrogen in the lysimeter might have induced higher yields and thus crop residues at the lysimeter compared to the surrounding fields. Percolating water and nitrogen may also be accumulating at the lysimeter bottom, since collection depth of the lysimeters is much higher

Table 3 Nitrogen losses through leaching $\left(\mathrm{N}_{(\mathrm{L}) \_t t}\right)$, nitrogen sources $\left(\mathrm{F}_{\mathrm{SN} \_ \text {tot }}, \mathrm{F}_{\mathrm{ON} \_ \text {tot }}, \mathrm{F}_{\mathrm{CR}_{\_} \text {tot }}\right)$ for the whole evaluation evaluation period $\left(\mathrm{Frac}_{\mathrm{LEACH} \_t o t}\right)$ and as a mean of annual values $\left(\right.$ Frac $\left._{\text {LEACH_mean }}\right)$, standard deviation of annual values (SD), number of years of observation (n)

\begin{tabular}{|c|c|c|c|c|c|c|c|c|c|}
\hline Site & $\begin{array}{l}\mathrm{N}_{(\mathrm{L}) \text { tot }} \\
\left(\mathrm{kg} \mathrm{N} \mathrm{ha}{ }^{-1}\right)\end{array}$ & $\begin{array}{l}\mathrm{F}_{\mathrm{SN} \_t o t} \\
\left(\mathrm{~kg} \mathrm{~N} \mathrm{ha}^{-1}\right)\end{array}$ & 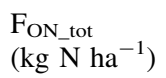 & $\begin{array}{l}\mathrm{F}_{\mathrm{CR} \text { tot }} \\
\left(\mathrm{kg} \mathrm{N} \mathrm{ha}{ }^{-1}\right)\end{array}$ & Frac $_{\text {LEACH_tot }}$ & Frac $_{\text {LEACH_mean }}$ & $\mathrm{SD}$ & $\mathrm{n}$ & Land use \\
\hline Petz 1 & 225 & 908 & 366 & 357 & 0.138 & 0.288 & 0.390 & 5 & Arable land \\
\hline Petz $_{\text {syn }} 1$ & 278 & 0 & 506 & 398 & 0.307 & 0.565 & 0.541 & 5 & \\
\hline $\mathrm{Wag}_{\text {con }} 1$ & 638 & 1608 & 0 & 910 & 0.253 & 0.261 & 0.172 & 10 & \\
\hline Wag $_{\text {con }} 2$ & 164 & 548 & 476 & 1151 & 0.075 & 0.121 & 0.120 & 8 & \\
\hline Wag $_{\text {bio }} 1$ & 818 & 1370 & 293 & 1077 & 0.299 & 0.330 & 0.278 & 10 & \\
\hline Wag $_{\text {bio }} 2$ & 270 & 0 & 0 & 1625 & 0.166 & 0.309 & 0.398 & 8 & \\
\hline Peba 1 & 479 & 1571 & 769 & 1552 & 0.123 & 0.153 & 0.147 & 18 & \\
\hline Peba 3 & 301 & 116 & 1888 & 1568 & 0.084 & 0.088 & 0.059 & 18 & \\
\hline Puck 1 & 815 & 725 & 793 & 885 & 0.921 & 0.832 & 1.126 & 16 & \\
\hline Lob 1 & 183 & 0 & 0 & 1041 & 0.176 & 0.207 & 0.151 & 13 & \\
\hline Lob 2 & 248 & 0 & 285 & 929 & 0.204 & 0.230 & 0.173 & 13 & \\
\hline Lob 3 & 241 & 302 & 0 & 1087 & 0.173 & 0.240 & 0.230 & 13 & \\
\hline $\operatorname{Hir}_{\mathrm{s}}$ & 168 & 0 & 311 & 156 & 0.359 & 0.416 & 0.241 & 4 & \\
\hline $\mathrm{Hir}_{\mathrm{t}}$ & 163 & 0 & 373 & 203 & 0.282 & 0.320 & 0.152 & 4 & \\
\hline Petz 2 & 36 & 0 & 0 & 2279 & 0.016 & 0.018 & 0.015 & 6 & Grassland \\
\hline Petz $_{\text {syn }} 2$ & 18 & 0 & 0 & 1753 & 0.011 & 0.010 & 0.011 & 4 & \\
\hline Peba 2 & 121 & 955 & 597 & 708 & 0.054 & 0.057 & 0.033 & 6 & \\
\hline Gump 1 & 3 & 120 & 0 & 201 & 0.011 & 0.010 & 0.012 & 3 & \\
\hline Gump 2 & 5 & 238 & 0 & 327 & 0.008 & 0.007 & 0.009 & 3 & \\
\hline Gump 3 & 23 & 214 & 0 & 319 & 0.043 & 0.038 & 0.053 & 3 & \\
\hline Gump 4 & 4 & 311 & 0 & 377 & 0.006 & 0.006 & 0.002 & 3 & \\
\hline Gump 5 & 13 & 409 & 0 & 331 & 0.017 & 0.018 & 0.004 & 3 & \\
\hline
\end{tabular}

Frac $_{\text {LEACH_tot }}($ bold column in the table) is the main result of the various lysimeter sites 
than rooting depth for cereals $(\sim 110 \mathrm{~cm})$, the main crops at Hirschstetten and Lobau. In this case nitrogen will not be taken up by the plants but leached when water content is higher than field capacity. Probably both situations will occur because of the disturbed soil water regime especially at the lysimeter bottom and its interplay with drier soil horizons and plant roots.

However, the errors we cause by correcting leaching rate, are much smaller compared to the errors of the wrongly measured leaching rates. While underestimated leaching rates directly influence Frac $_{\text {LEACH }}$ (Eq. 2), enlarged nitrogen pools affect Frac $_{\text {LEACH }}$ indirectly through increased harvest and thus crop residues which are approximately one-third of harvest nitrogen.

\section{Calculation of Frac $\mathrm{LEACH}_{\mathrm{LE}}$ (only leaching)}

We used two different methods for estimating Frac $_{\text {LEACH. }}$. The first method was the mass balance of the whole time series of the individual sites. Second, we calculated annual Frac LEACH $_{\text {values and their mean }}$ and standard deviation to analyse the annual variability. Of course, the sum of the ratios is not the same as the ratio of the sums, so the second method will be less representative of the long term mean.

In general, the grassland sites show significantly lower values of Frac $_{\text {LEACH }}$ compared to those on arable land (Table 3). The arithmetic mean over all grassland sites is 0.021 , while on arable land it is 0.254 . The highest single annual value for Frac $_{\mathrm{LEACH}}$ on grassland was calculated for the Pettenbach site (0.11 in 1995), where mineral fertilizer was applied in addition to the manure/slurry from pig and cattle. Based on currently valid fertilizer recommendations (BMLFUW 2006) this site was affected by a surplus of fertilizer of $44 \%$ on average.

For grassland, the temporal resolution for the evaluation plays a minor role (annually or over the entire observation period), as the variability between years is small. The annual variability is very low due to similar annual nitrogen requirements of the permanent vegetation in different years. Fluctuations may arise due to rainfall and evaporation, and a different number or different timing of mowing cycles. In Austria most of the grassland is usually grazed either permanently or after a certain number of cuts (for hay production and winter feeding). But grazing does not increase FracLeach because additional $\mathrm{N}$ input from grazing animals must be taken into account, when farmers plan their fertilizer management. The Austrian fertilization guideline (BMLFUW 2006) provides thresholds, which must not be exceeded. If farmers let the animals graze, the amount of manure fertilizer must be reduced according to these guidelines. Therefore, dung and urine (from grazing animals is not a surplus but substitute.

The arable sites, generally, show higher values of Frac $_{\text {LEACH. They also exhibit a significant annual }}$ variability due to variations in crop rotation and fertilization rate, yields and climate conditions. In addition, the time factor of the mineralization of plant residues plays an important role (David et al. 1997). In our calculations, the mineralization pool of crop residues has been allocated to the year of harvest, although mineralization and transport will take place over a longer period. Therefore, the annual calculation of Frac $_{\mathrm{LEACH}}$ for a single site may not be representative of the longer term mean.

Nevertheless, the annual approach is able to highlight special features of nitrogen leaching. The problem of time delay through mineralization and transport of nitrogen in the soil can be well represented at the Petzenkirchen site, as there was a land use change (Fig. 3). After harvesting of maize, the field was converted into permanent fallow in August 1994. The yields of maize in the year of change were very low leaving a large pool of nitrogen remaining in the soil. Thus, in the first months of the following year the highest nitrogen leaching rates were measured with a significant delay.

Individual years can give much larger Frac $_{\mathrm{LEACH}}$ values than the long term average due to carry over effects between years. The highest annual values for Frac $_{\text {LEACH }}$ of all observation sites were observed at the Pucking site in those years in which soybean was grown with a maximum of Frac $_{\mathrm{LEACH}}=3.60$. This high value appeared because neither a mineral nor an organic fertilization was applied, which leads to a small denominator in Eq. 2. All legumes (Fabacea) tend to show high values of Frac $_{\mathrm{LEACH}}$ due to the usually reduced or even absent fertilization.

We conducted a spearman correlation test with the factors rainfall, annual seepage, field capacity, soil depth, sampling depth, yield, $\mathrm{N}$ yield, $\mathrm{N}$ fertilization and $\mathrm{N}$ leached. Texture is represented through field capacity of soil. We left out chemistry which was not sufficiently available at the different sites. The correlation was done for single years, but also for the means 
Fig. 3 Leaching rates and nitrogen content in seepage water for the Petzenkirchen site

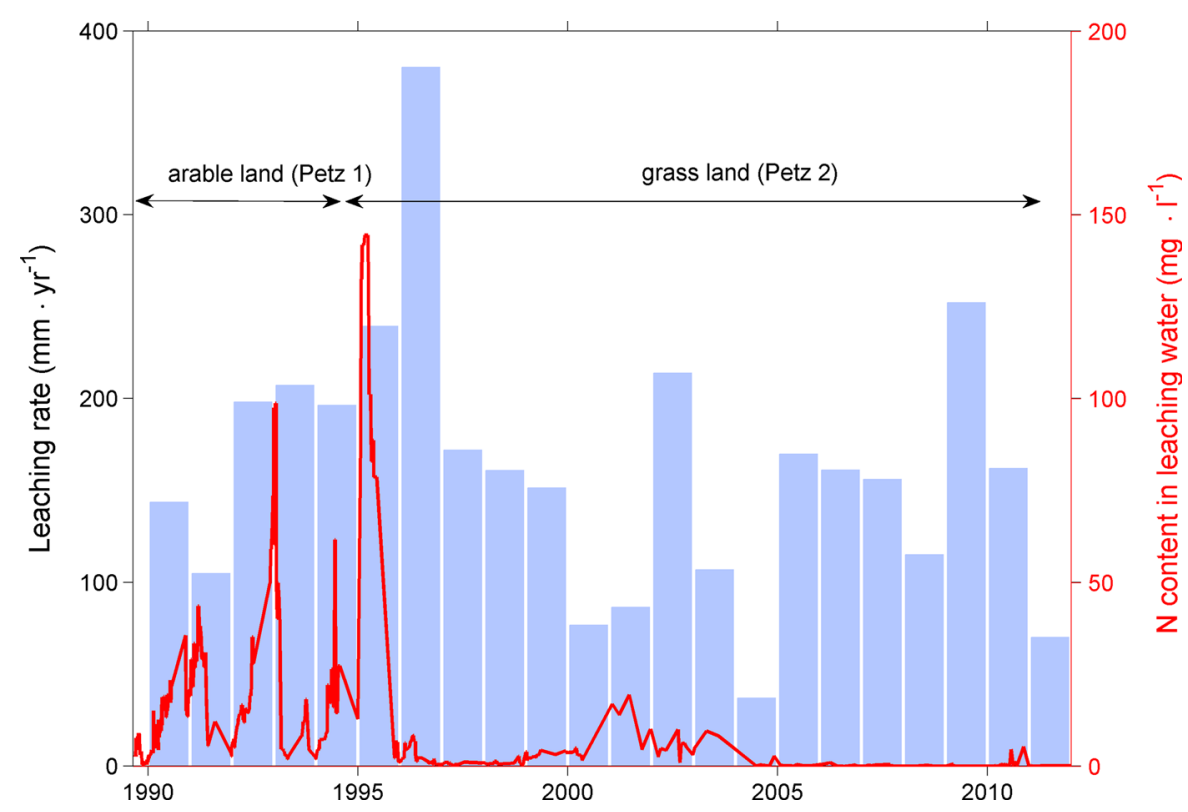

of the entire observation period. Significant correlation is displayed at Table 4 in the paper.

As deducible from this table, behaviour of Frac $_{\text {LEACH }}$ is related only to a certain extent to single factors related to the environmental background of a site. Also the relationships between the single factors and Frac $_{\text {LEACH }}$ may be highly nonlinear. In the case of the relationship between Frac $_{\text {LEACH }}$ and field capacity of soil for instance, an exponential relationship was found $\left(\mathrm{r}^{2}=-0.28\right.$, not shown). We then performed multiple regression including the significant factors drainage, field capacity, soil depth, $\mathrm{N}$ yield and $\mathrm{N}$ fertilization. This resulted in $\mathrm{ar}^{2}$ of 0.47 . These results indicate that site characteristics alone are only partially responsible for the value of FRACLEACH. Much more it is depending on the actual management practices at a site as also found by Kirchmann et al. (2002), Feichtinger et al. (2008) and Jia et al. (2014).

Nitrogen loss

Although a high Frac $_{\text {LEACH }}$ indicates poor nitrogen uptake it may not necessarily indicate a high absolute nitrogen transport to groundwater. As an example, the nitrogen losses for soybeans in Pucking were only around the average of all crops $\left(51 \mathrm{~kg} \mathrm{ha}^{-1} \mathrm{a}^{-1}\right)$.

The highest nitrogen losses took place at the Wagna site during the period when the main focus of research was on increasing yields. The mean nitrogen loss was $96 \mathrm{~kg} \mathrm{ha}^{-1} \mathrm{a}^{-1}$ with a maximum for lysimeter $\mathrm{Wag}_{\text {bio }}$ 1 with $170 \mathrm{~kg} \mathrm{ha}^{-1} \mathrm{a}^{-1}$ in 1996. This can be explained by the high input of fertilizer on this site, which was $48 \%$ higher than the $\mathrm{N}$-input recommended by official guidelines from nowadays (BMLFUW 2006). In addition to high amounts of fertilizers, high annual rainfall resulting in high seepage rates increased nitrogen leaching to the groundwater (Fig. 4). Although high $\mathrm{N}$ losses by leaching were observed at the Wagna site, the average values of Frac ${ }_{\mathrm{LEACH}}$ for the four lysimeters were below $\left(0.25\right.$ at $\mathrm{Wag}_{\text {con }} 1,0.08$ at $\mathrm{Wag}_{\text {con }}$ and 0.17 at $\mathrm{Wag}_{\text {bio }} 2$ ) or close to the IPCC default value of 0.3 (0.30 at $\mathrm{Wag}_{\text {bio }} 1 ; 0.31$ at $\mathrm{Wag}_{\text {bio }} 2$ ).

In general, high seepage water rates tend to result in both high Frac LEACH $_{\text {values and high nitrogen losses }}$ through leaching. A comparison of the sites suggests that deep soil profiles with higher available field capacity produce less nitrogen loss through leaching (see also Table 4). This can be demonstrated for the 
Table 4 Correlation coefficient (Spearman) for rainfall (P), annual seapage (L), field capacity (FC), soil depth (d), sampling depth (z), nitrogen export through harvest $(\mathrm{NH})$, nitrogen losses through leaching (NL) and organic fertilizer
(FON) influencing FracLEACH for single years (FracLEACH single) and the means of the entire observation period (FracLEACH means)

\begin{tabular}{llllllrrr}
\hline & $\mathrm{P}$ & $\mathrm{L}$ & $\mathrm{FC}$ & $\mathrm{d}$ & $\mathrm{z}$ & $\mathrm{N}_{\mathrm{H}}$ & $\mathrm{N}_{\mathrm{L}}$ & $\mathrm{F}_{\mathrm{ON}}$ \\
\hline Frac $_{\text {LEACH_single }}(\mathrm{n}=136)$ & 0.35 & 0.65 & -0.31 & -0.49 & -0.22 & 0.20 & 0.92 & 0.21 \\
Frac $_{\text {LEACH_means }}(\mathrm{n}=16)$ & 0.23 & 0.38 & -0.50 & -0.60 & -0.35 & 0.16 & 0.86 & 0.21 \\
\hline
\end{tabular}

Fig. 4 Annual values of Frac $_{\text {LEACH }}$ as a function of annual seepage water for the lysimeters analysed. Sites closely located to each other (exhibiting similar meteorological conditions) are displayed in the same design

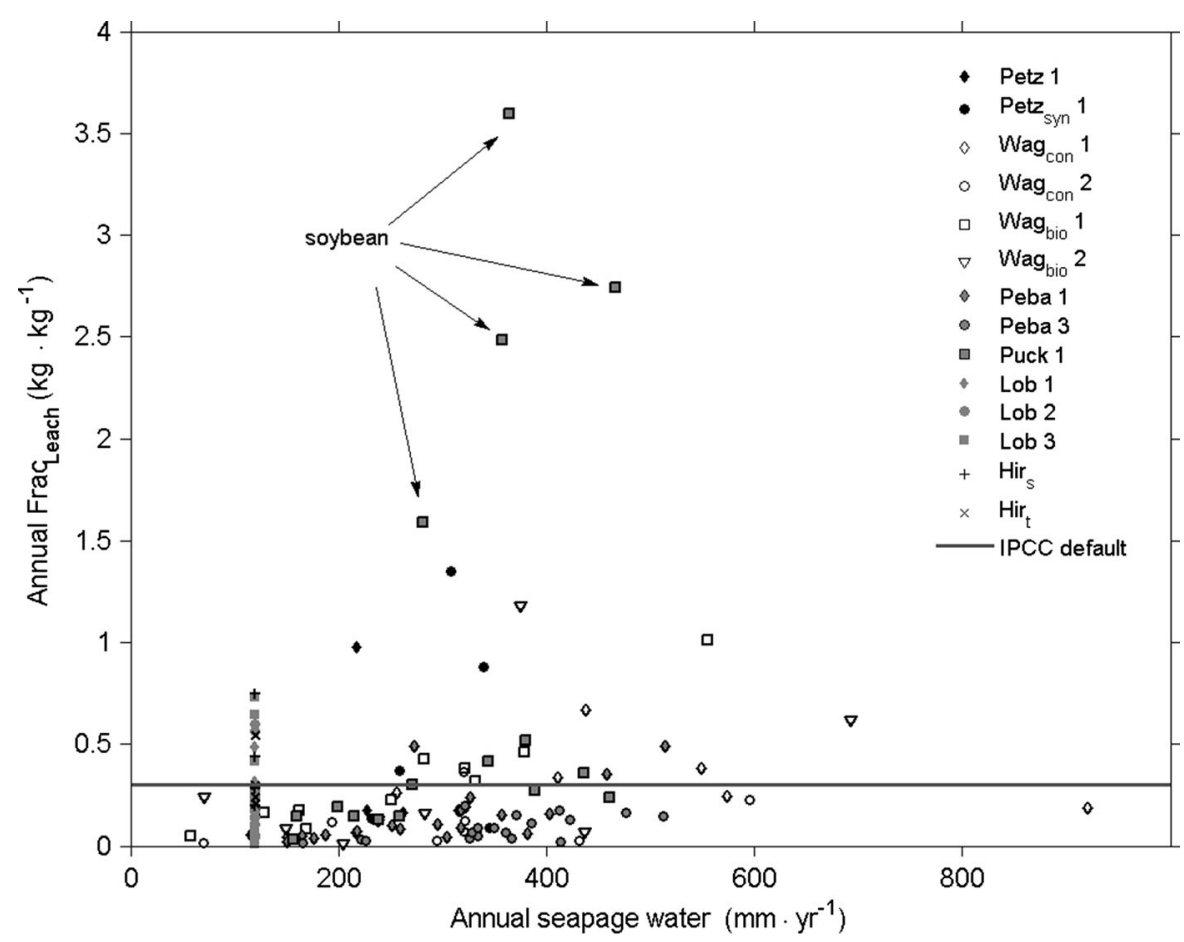

Pettenbach and Pucking sites (Fig. 5). The lysimeters are close to each other and are subject to the same climatic conditions. The trend line for nitrogen losses of the shallow Pucking site with only $60 \mathrm{~cm}$ topsoil (Puck 1) and a field capacity of only $112 \mathrm{~mm}$ within these $60 \mathrm{~cm}$ of topsoil due to the sandy soil is above the trend lines for Peba 1 and Peba 3 with 150 and $110 \mathrm{~cm}$ topsoil and 534 and $396 \mathrm{~mm}$ field capacity, respectively. The same annual seepage water led to higher nitrogen losses at the Puck 1 site compared to the Peba 1 and Peba 3 sites although, at Puck 1 site, only $80 \%$ of the recommended amount of fertilizer was applied. In contrast Peba 3 and Peba 1 sites were fertilized with 95 and $122 \%$ of the recommended amount of fertilizer.

Another aspect of exceptionally high nitrogen contents in the leaching water and high values of Frac $_{\text {LEACH }}$ can be related to the nitrogen stock in the soil. On the one hand, a high nitrogen stock in the soil may occur if a lot of above ground and/or below ground plant residues are incorporated into the soil for later mineralization. On the other hand, a poorly developed plant mass of the previous crop in combination with fertilizer supply may leave considerable amounts of nitrogen in the soil. When a poor plant development coincided with rainy periods, high nitrogen losses were measured. This was observed in 2008 at the Lobau site. Although the crop was potatoes which need high nitrogen fertilization, the poor development of green pea in the previous year led to nitrogen losses of $60 \mathrm{~kg} \mathrm{ha}^{-1} \mathrm{a}^{-1}$ (Lob2) and $80 \mathrm{~kg} \mathrm{ha}^{-1} \mathrm{a}^{-1}$ (Lob3). In addition to the increase of nitrogen in the soil due to incorporation of the green pea biomass, the nitrogen stock in the soil was increased by nitrogen fixation. At the Lob1 site, the 
Fig. 5 Annual nitrogen losses through leaching as a function of annual seepage water on arable sites. Sites closely located to each other (exhibiting similar meteorological conditions) are displayed in the same design

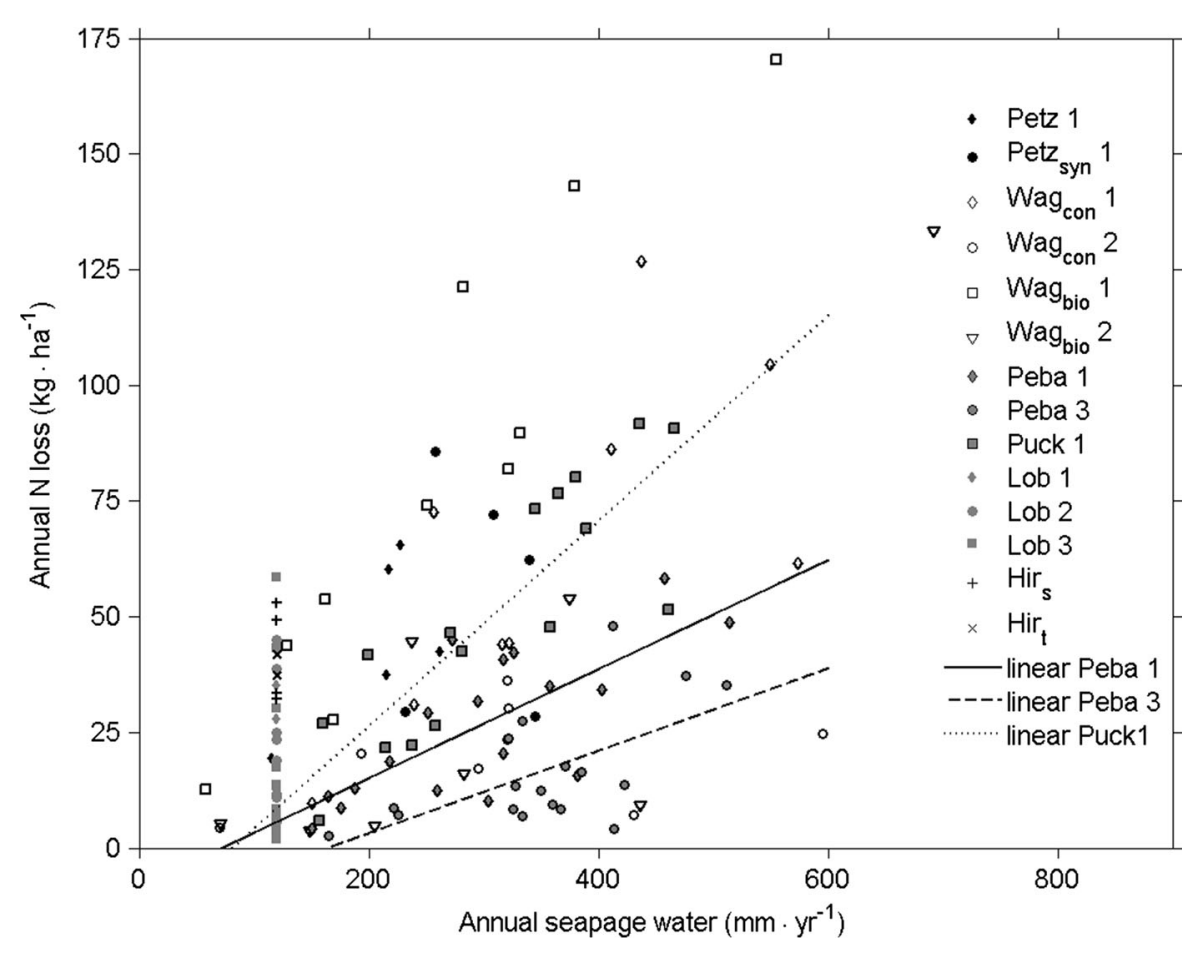

zero fertilizer lysimeter at Lobau, only $20 \mathrm{~kg} \mathrm{ha}^{-1}$ $\mathrm{a}^{-1}$ nitrogen losses through leaching were measured. However, compared to usual nitrogen losses (14 $\mathrm{kg} \mathrm{ha}^{-1} \mathrm{a}^{-1}$ on average) at this site, the large nitrogen stock in the soil almost doubled the nitrogen losses in 2008.

Consequently, the calculated Frac $_{\text {LEACH }}$ values were significantly lower than those suggested by the IPCC Guidelines (IPCC 2006). However, in the IPCC guidelines nitrogen losses from both leaching and runoff are considered. The latter is not reflected in the lysimeters measurements since they are installed on flat fields and no surface runoff occurs.

\section{Calculation of $\mathrm{Frac}_{\mathrm{LEACH}} *$ (leaching and runoff)}

For a mountainous country like Austria, any calcula-

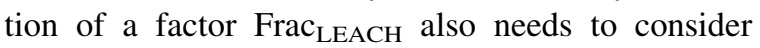
nitrogen losses via lateral pathways (surface runoff, subsurface runoff, drainage) (Table 5).

Nitrate concentrations of surface runoff and therefore also nitrogen losses through runoff are often small compared to the nitrate losses through leaching
(Jackson et al. 1973; Casson et al. 2008). Sharpley et al. (1987) found that 3-9\% of nitrogen fertilizer input was lost to surface runoff for an 8 year monitoring project of 20 catchments in Texas and Oklahoma. However, these results refer to different agroecological environments compared to Austrian conditions. Unfortunately, the data base for calculation of a runoff component for $\mathrm{Frac}_{\mathrm{LEACH}}$ in Austria is not sufficiently developed yet. To consider losses by runoff we therefore used results of a simulation study to derive pathways of nitrogen losses at the scale of all of Austria (BMLFUW 2011). We added simulated nitrogen inputs to rivers from overland flow $\left(10,321 \mathrm{t} \mathrm{year}^{-1}\right)$, snow melt $\left(535 \mathrm{t} \mathrm{year}^{-1}\right)$ and drainages $\left(2732 \mathrm{t} \mathrm{year}^{-1}\right.$ ) and divided this amount with simulated inputs from groundwater (45425 $\mathrm{t} \mathrm{year}^{-1}$ ), resulting in a contribution of $30 \%$ of the total nitrogen losses for pathways related to lateral flow processes. The number of $30 \%$ can be considered an upper bound of possible losses because BMLFUW (2011) also included emissions from forests, alpine regions and the atmospheric nitrogen input in addition to the input data which would be 
Table 5 Measured nitrogen losses through leaching ( $\mathrm{N}_{(\mathrm{L}) \_ \text {leach- }}$ ing $)$, calculated nitrogen losses through runoff $\left(\mathrm{N}_{(\mathrm{L}) \text { _runoff }}\right)$, total nitrogen losses through leaching and runoff( $\left(\mathrm{N}_{(\mathrm{L})}\right)$, nitrogen

\begin{tabular}{|c|c|c|c|c|c|c|}
\hline Site & $\begin{array}{l}\mathrm{N}_{(\mathrm{L}) \_ \text {leaching }} \\
\left(\mathrm{kg} \mathrm{N} \mathrm{ha}^{-1}\right)\end{array}$ & $\begin{array}{l}\mathrm{N}_{(\mathrm{L}) \_ \text {runoff }} \\
\left(\mathrm{kg} \mathrm{N} \mathrm{ha}^{-1}\right)\end{array}$ & $\begin{array}{l}\mathrm{N}_{(\mathrm{L})}^{\mathrm{a}} \\
\left(\mathrm{kg} \mathrm{N} \text { ha }^{-1}\right)\end{array}$ & $\begin{array}{l}\mathrm{F}_{\mathrm{SN}}+\mathrm{F}_{\mathrm{ON}}+\mathrm{F}_{\mathrm{CR}} \\
\left(\mathrm{kg} \mathrm{N} \mathrm{ha}^{-1}\right)\end{array}$ & $\operatorname{Frac}_{\text {LEACH }}{ }^{a}$ & Land use \\
\hline Petz 1 & 225 & 68 & 293 & 1632 & 0.180 & Arable land \\
\hline Petz $_{\text {syn }} 1$ & 278 & 83 & 361 & 904 & 0.399 & \\
\hline $\mathrm{Wag}_{\text {con }} 1$ & 638 & 191 & 830 & 2518 & 0.329 & \\
\hline $\mathrm{Wag}_{\text {con }} 2$ & 164 & 49 & 213 & 2175 & 0.098 & \\
\hline Wag $_{\text {bio }} 1$ & 818 & 245 & 1064 & 2740 & 0.388 & \\
\hline Wag $_{\text {bio }} 2$ & 270 & 81 & 351 & 1625 & 0.216 & \\
\hline Peba 1 & 479 & 144 & 623 & 3892 & 0.160 & \\
\hline Peba 3 & 301 & 90 & 391 & 3572 & 0.109 & \\
\hline Puck 1 & 815 & 245 & 1060 & 2403 & 0.441 & \\
\hline Lob 1 & 183 & 55 & 238 & 1041 & 0.229 & \\
\hline Lob 2 & 248 & 74 & 323 & 1214 & 0.266 & \\
\hline Lob 3 & 241 & 72 & 313 & 1389 & 0.225 & \\
\hline $\operatorname{Hir}_{\mathrm{s}}$ & 168 & 50 & 218 & 467 & 0.467 & \\
\hline $\mathrm{Hir}_{\mathrm{t}}$ & 163 & 49 & 211 & 575 & 0.367 & \\
\hline Petz 2 & 36 & 11 & 47 & 2279 & 0.020 & Grassland \\
\hline Petz $_{\text {syn }} 2$ & 18 & 6 & 24 & 1753 & 0.014 & \\
\hline Peba 2 & 121 & 36 & 157 & 2260 & 0.070 & \\
\hline Gump 1 & 3 & 1 & 4 & 322 & 0.014 & \\
\hline Gump 2 & 5 & 1 & 6 & 564 & 0.010 & \\
\hline Gump 3 & 23 & 7 & 30 & 533 & 0.056 & \\
\hline Gump 4 & 4 & 1 & 5 & 688 & 0.008 & \\
\hline Gump 5 & 13 & 4 & 17 & 740 & 0.022 & \\
\hline
\end{tabular}

sources $\left(\mathrm{F}_{\mathrm{SN}}+\mathrm{F}_{\mathrm{ON}}+\mathrm{F}_{\mathrm{CR}}\right)$, corrected values for Frac $_{\mathrm{LEACH}}$ $\left(\right.$ Frac $\left._{\text {LEACH }}{ }^{a}\right)$ and land use 
Austria then is 0.15 . This is a considerably smaller value than the default value of $\mathrm{Frac}_{\mathrm{LEACH}}$ proposed by IPCC.

This calculation of the nitrogen losses through leaching and runoff may certainly be further improved by upscaling of site results using more detailed regional characteristics of land management and soil properties. A comparison of FracLeach to main environmental parameters has revealed that the complexity of the interactions between these parameters is the main driver of changing values for FracLeach. As a basis for an upscaling of the results obtained, process based models may be employed which are able to deal with a large variety of different climate-soil-land management interactions. These models may be calibrated using results of this lysimeter study. Further research is also necessary for hilly land, where nitrogen losses occur through a combination of seepage, subsurface flow and surface flow.

Open Access This article is distributed under the terms of the Creative Commons Attribution License which permits any use, distribution, and reproduction in any medium, provided the original author(s) and the source are credited.

\section{References}

BMLFUW-Bundesministerium für Land-und Forstwirtschaft, Umwelt und Wasser (2006) Richtlinien für die Sachgerechte Düngung. Anleitung zur Interpretation von Bodenuntersuchungsergebnissen in der Landwirtschaft. 6 . Auflage, Bundesministerium für Land-und Forstwirtschaft, Umwelt und Wasser, 79 S., Wien

BMLFUW-Bundesministerium für Land-und Forstwirtschaft, Umwelt und Wasser (2011) Stoffbilanzmodellierung für Nährstoffe auf Einzugsgebietsebene als Grundlage für Bewirtschaftungspläne und Maßnahmenprogramme. Bundesministerium für Land-und Forstwirtschaft, Umwelt und Wasser, 190 S., Wien

Braun M, Hurni P, Spiess E (1994) Phosphor-und Stickstoffüberschüsse in der Landwirtschaft und Para-Landwirtschaft : Abschätzung für die Schweiz und das Rheineinzugsgebiet der Schweiz unterhalb der Seen. Schriftenreihe der FAC Liebefeld 18, Bern

Casson JP, Olson BM, Little JL, Nolan SC (2008) Assessment of environmental sustainability in Alberta's agricultural watersheds project, Volume 4, Nitrogen loss in surface runoff. Alberta Agriculture and Rural Development: Lethbridge, $\mathrm{p} 71$

Chichester FW (1977) Effects of increased fertilizer rates on nitrogen content of runoff and percolate from monolith lysimeters. J Environ Qual 6:211-217. doi:10.2134/ jeq1977.00472425000600020023x
David MB, Gentry LE, Kovacic DA, Smith KM (1997) Nitrogen balance in and export from an agricultural watershed. J Environ Qual 26:1038-1048. doi:10.2134/jeq1997. 00472425002600040015x

Del Prado A, Brown L, Schulte R, Ryan M, Scholefield D (2006) Principles of development of a mass balance $\mathrm{N}$ cycle model for temperate grasslands: an Irish case study. Nutr Cycl Agroecosyst 74:115-131. doi:10.1007/s10705-005-5769-z

Dowdell RJ, Webster CP (1980) A lysimeter study using nitrogen- 15 on the uptake of fertilizer nitrogen by perennial ryegrass swards and losses by leaching. Eur J Soil Sci 31:65-75. doi:10.1111/j.1365-2389.1980.tb02065.x

European Council (EC) (1991) Council regulation No 2092/91 of June 1991 on organic production of agricultural products and indications referring thereto on agricultural products and foodstaff. http://eur-lex.europa.eu/LexUriServ/ LexUriServ.do?uri=CONSLEG:1991R2092:20080514:EN: PDF. Accessed 7 Apr 2014

Environment Agency Austria (2013) Austria's national inventory report 2013-agriculture (CRF Sector 4). Environment Agency Austria, Vienna, pp 260-322

Environmental Protection Agency Ireland: National inventory report (2011). Greenhouse gas emissions 1990-2009 reported to the UPFCCC. Wexford

Erhart E, Feichinger F, Hartl W (2007) Nitrogen leaching losses under crops fertilized with biowaste compost compared with mineral fertilization. J Plant Nutr Soil Sci 170: 608-614. doi:10.1002/jpln.20062518

Feichtinger F, Dorner J, Aigner F (2004) Durchschnittliche Versickerungsmengen und bewirtschaftungsbedingte Stickstoffausträge im Alpenvorland Niederösterreichs. Schriftenreihe des Bundesamt für Wasserwirtschaft 20:79-90

Feichtinger F, Strauss P, Lescot JM, Kaljonen M, Hofmacher G (2008) Integrated assesment of groundwater protection using agricultural best managment practices-a nitrogen case study. Die Bodenkultur 59(1-4):149-164

Herndl M, Schink M, Kandolf M, Bohner A, Buchgraber K (2013) Nährstoffauswaschung im Grünland in Abhängigkeit vom Wirtschaftsdüngungs- und Nutzungssystem, Conference Proceeding: 15. Dumpensteiner Lysimetertagung 2013, Raumberg-Gumpenstein, 25-30, ISBN: 978-3902559-90-6

IPCC (2000) Good practice guidelines and uncertainty management in national greenhouse gas inventories. Prepared by the National Greenhouse Gas Inventories Programme. In: Penman J, Kruger D, Galbally I, Hiraishi T, Nyenzi B, Emmanul S, Buendia L, Hoppaus R, Martinsen T, Meijer J, Miwa K, Tanabe K (eds) IGES, Japan, ISBN 4-88788-000-6

IPCC (2006) IPCC guidelines for national greenhouse gas inventories, prepared by the National Greenhouse Gas Inventories Programme. In: Eggelston HS, Buendia L, Miwa K, Ngara T, Tanabe K (eds) IGES, Japan, ISBN 4-88788$032-4$

Jackson WA, Asmussen IE, Hauser EW, White AW (1973) Nitrate in surface and subsurface flow from a small agricultural watershed. J Environ Qual 2:480-482. doi:10. 2134/jeq1973.00472425000200040017x

Jia XC, Shao LJ, Liu P, Zhao BQ, Gu LM, Dong ST, Bing SH, Zhang JW, Zhao B (2014) Effect of different nitrogen and irrigation treatments on yield and nitrate leaching of 
summer maize (Zea mays L.) under lysimeter conditions. Agric Water Manag 137:92-103

Kirchmann H, Johnston AEJ, Bergstrom LF (2002) Possibilities for reducing nitrate leaching from agricultural land. Ambio 31(5):404-408

Klammler G, Fank J (2014) Determining water and nitrogen balances for beneficial management practices using lysimeters at Wagna test site (Austria). Sci Total Environ 449:448-462. doi:10.1016/j.scitotenv.2014.06.009

Kroeze C, Aerts R, van Breemen N, van Dam D, van der Hoek K, Hofschreuder P, Hoosbeek M, de Klein J, Kros H, van Oene H, Tietema A, van der Veeren R, de Vries W (2003) Uncertainties in the fate of nitrogen I: an overview of sources of uncertainty illustrated with a Dutch case study. Nutr Cycl Agroecosyst 66:43-69. doi:10.1023/A: 1023339106213

Mosier A, Kroeze C, Nevison C, Oenema O, Seitzinger S, van Cleemput O (1998) Closing the global $\mathrm{N}_{2} \mathrm{O}$ budget: nitrous oxide emissions through the agricultural nitrogen cycleOECD/IPCC/IEA phase II developement of IPCC guidelines for national greenhouse gas inventory methodology. Nutr Cycl Agroecosyst 52:225-248. doi:10.1023/A: 1009740530221

Murer E (2002) Erfassung und Bewertung der Sickerwasserquantität und-qualität im Pilotprojekt zur Grundwassersanierung in Oberösterreich. Monolithische Feldlysimeter. Schriftenreihe des Bundesamtes für Wasserwirtschaft 16:112-139

Neill M (1989) Nitrate concentrations in river waters in the south-east of Ireland and their relationship with agricultural practice. Water Res 23:1339-1355. doi:10.1016/ 0043-1354(89)90073-0

Prasuhn V, Braun M (1994) Abschätzung der Phosphor-und Stickstoffverluste aus diffusen Quellen in die Gewässer des Kantons Bern. Schriftenreihe der FAC Liebefeld 17. Bern

Prasuhn V, Mohni R (2003) GIS-gestützte Abschätzung der Phosphor-und Stickstoffeinträge aus diffusen Quellen in die Gewässer des Kantons Bern. FAL, interner Bericht z.H.
Amt für Gewässerschutz und Abfallwirtschaft, Kanton Bern. Zürich-Reckenholz

Ryan M, Brophy C, Connolly J, McNamara K, Carton OT (2006). Monitoring of nitrogen leaching on a dairy farm during four drainage seasons. Irish J Agric Food Res. 45: 115-134. http://www.jstor.org/stable/25562571. Accessed 28 Aug 2014

Scholefield D, Tyson KC, Garwood EA, Armstrong AC, Hawkins J, Stone AC (1993) Nitrate leaching from grazed grassland lysimeters: effects of fertilizer input, field drainage, age of sward and patterns of weather. Eur J Soil Sci 44:553-749. doi:10.1111/j.1365-2389.1993.tb02325.x

Sharpley AN, Smith SJ, Naney JW (1987) Environmental impact of agricultural nitrogen and phosphorus use. J Agric Food Chem 35:812-817

Stenitzer E (1988) Simwaser-Ein numerisches Modell zur Simulation des Bodenwasserhaushaltes und des Pflanzenertrages eines Standortes. Mitteilungen aus der Bundesanstalt für Kulturtechnik und Bodenwasserhaushalt 31, Petzenkirchen

Stenitzer E, Fank J (2008) Schwerkraft-versus Unterdrucklysimeter-eine Simulationsstudie. In diffuse Einträge in das Grundwasser: Monitoring-ModellierungManagement, Landwirtschaft und Wasserwirtschaft im Fokus zu erwartender Herausforderungen. Beiträge zur Hydrogeol 56:114-118 Graz

Thomas SM, Ledgard SF, Francis GS (2005) Improving calculates of nitrate leaching for quantifying New Zealand's indirect nitrous oxide emissions. Nutr Cycl Agroecosyst 73:213-226. doi:10.1007/s10705-005-2476-8

von Unold G, Fank J (2008) Modular design of field lysimeters for specific application needs. Water Air Soil Pollut Focus 8:233-242. doi:10.1007/s11267-007-9172-4

Williamson JC, Taylor MD, Torrens RS, Vojvodic-Vukovic M (1998) Reducing nitrogen leaching from dairy farm effluent-irrigated pasture using dicyandiamide: a lysimeter study. Agric Ecosyst Environ 69:81-88. doi:10.1016/ S0167-8809(98)00099-1 